\title{
The International Context: EU and WHO
}

Since the 1960s, governments around the world have been developing policies to control tobacco. Countries have employed different combinations of measures (World Bank, 1999), taking national circumstances into account. For example, the United Kingdom attached importance to building a national infrastructure of smoking cessation support in combination with having the highest cigarette prices in Europe, while Australia invested in mass media campaigns and was at the forefront of pictorial health warnings and plain packaging, in addition to high tobacco taxes. In contrast, the United States combined strong smoking bans to protect non-smokers, with restrictions on the sale of tobacco to youth and a long history of litigation against the tobacco industry, but has relatively low cigarette taxes, modest health warnings on cigarette packs, and weak advertising restrictions (Kagan \& Nelson, 2001). Despite such differences, there is an increasing convergence of strategies across countries (Studlar, 2006). There are two aspects to this. The first is the process of governments and tobacco control coalitions becoming inspired by countries that lead the way, facilitated by increased levels of corporation and coordination of tobacco control advocacy at the international level. The second is the emergence of "hard" international law to which national governments need to abide. This is facilitated by supranational legislation from the EU and WHO forcing countries to adopt similar policies. In Europe these processes add two extra layers of governance above the national and

M. C. Willemsen, Tobacco Control Policy in the Netherlands, Palgrave Studies in Public Health Policy Research, https://doi.org/10.1007/978-3-319-72368-6_6 
sub-national levels, and as a result tobacco control policymaking has become the outcome of a continuous negotiation among nested governments at several tiers, a process which has been described as multi-level governance (Asare, Cairney, \& Studlar, 2009; Marks \& Hooghe, 2003).

The previous chapter discussed the division of responsibilities between the national and the local levels. The current chapter examines the relationship between the national and international levels. I start with EU policymaking, followed by an account of the emergence of WHO's Framework Convention on Tobacco Control (FCTC) and what this meant for Dutch national policymaking. A key part of FCTC is Article 5.3, which was included to assure that the tobacco industry is kept away from the process of making tobacco control policy.

\section{European Tobacco Control Policy}

The EU developed several mechanisms to coordinate and develop policymaking across EU countries. ${ }^{1}$ Nowadays tobacco control laws are part of the EU acquis communautaire, the body of laws by which countries that join the EU must abide.

During the first decades of tobacco control, no supranational coordination or legislation existed. The formulation of an EU tobacco control policy began in 1984, when tobacco control was mentioned for the first time as a potential EU task, next to drug addiction and prevention of infectious diseases (European Commission, 1984). The EU regarded it as its task to coordinate the various programmes and actions that individual member states were already taking against tobacco. In 1985 the European Council of Health Ministers announced a programme against cancer, in an attempt to bring the European project closer to the real concerns of Europeans-for cancer was a great concern to many. Smoking was given high priority within this programme, and the Europe Against Cancer programme became a catalyst for EU-initiated tobacco control (Gilmore \& McKee, 2004).

The EU developed various ways of controlling tobacco, and it is important to understand the differences. Directives, Decisions, and Regulations are legally binding, while Recommendations and Resolutions are not. Directives must first be transposed into national law and be adjusted to member states' particular circumstances, while Regulations have the immediate force of law. For tobacco control, Directives have 
been most important. The European Commission (EC) enforces Directives by sending notifications, then issuing warnings, and finally referring to the European Court of Justice when member states do not implement them in their national legislation (Asare et al., 2009). Noncompliance is punished by financial sanctions ("hard law"). Other tobacco control measures such as protection of non-smokers, education, and smoking cessation support are dealt with in Recommendations and Resolutions, which are not legally binding ("soft law"). In addition to hard and soft laws, the EU initiated and funded various tobacco control capacity building activities, such as the European Network of Smoking Prevention (ENSP) and media campaigns to discourage smoking in youth. The Europe Against Cancer programme consisted mainly of educational measures like media campaigns, but it inspired the EC to develop and adopt no less than six Directives, one Regulation, and one Resolution between 1989 and 1992 .

The swift adoption at the beginning of the 1990s of so many binding EU measures to control tobacco was possible because the tobacco industry had not yet developed a strong lobbying position in Brussels (Gilmore \& McKee, 2004) and the proposed measures were no real threat to individual EU countries since most had already implemented them-such as bans on tobacco advertising on television and text warnings on cigarette packs. In the course of the 1990s the tobacco lobby became more organised. It had some success in delaying or watering down EU initiatives, including tobacco advertising Directives and tobacco product Directives (Costa, Gilmore, Peeters, McKee, \& Stuckler, 2014; Hastings \& Angus, 2004; Peeters, Costa, Stuckler, McKee, \& Gilmore, 2016). However, its effectiveness should not be overrated. For example, in the case of the first Tobacco Product Directive (TPD-1), the industry was unable to prevent the directive from coming into force nor did it manage to dilute it, despite intensive lobbying (Mandal et al., 2009).

\section{The EU's Competence in Tobacco Control}

The 1986 Single European Act recognised, albeit in vague terms, health as a factor to take into account when strengthening European economic integration and building a single market, but the EU has never acquired a mandate to issue regulations solely for the sake of public health (Duina \& Kurzer, 2004). The EU's public health competence is laid 
down in article 152 EC (formerly Article 129), which requires that public health be protected in all EU policies and activities. However, the article excludes harmonisation of hard laws and Regulations and therefore cannot serve as a legal basis for tobacco control laws (Boessen \& Maarse, 2008; Mandal et al., 2009; Verschuuren, 2011). In the absence of a legal base to regulate smoking, the EU had to fall back on the creative use of other EU treaties (Boessen \& Maarse, 2008). After much debate it finally based its competence on tobacco control through $\mathrm{EU}$ jurisdiction concerning the internal market (Article $95 \mathrm{EC}$, formerly Article 100a). All EU tobacco legislation regarding labelling, advertising, and product regulation are founded on the EU's jurisdiction to ensure the free movement of goods and services throughout the $\mathrm{EU}$ (Verschuuren, 2011). This is not a clear-cut matter, since it requires the EC to show that tobacco control interventions, which in essence restrict markets, have at least an element that improves internal markets (Boessen \& Maarse, 2008). The EC argued that a uniform EU-wide tobacco advertising ban was necessary to end distortion of competition across borders, which might be the result if one country gave advertising agencies more freedom to promote tobacco in magazines and newspapers than did another.

EU's legal competence to control tobacco has frequently been disputed by the tobacco industry, and by some governments. The most notorious example was when the German government challenged the EU's jurisdiction to enforce tobacco advertising restrictions, resulting in an annulment by the European Court of Justice of the advertising Directive, after which the EC was forced to be content with a less comprehensive advertising ban (Mandal et al., 2009). The ban was proposed in 1989 and supported by several countries, notably Italy and France, for whom such a ban would confirm existing national legislation, while the United Kingdom, Denmark, Germany, and the Netherlands opposed and successfully vetoed proposals (Bitton, Neuman, \& Glantz, 2002) (see Box 6.1). Duina and Kurzer (2004) argue that these four countries shared "national traditions of libertarianism characterised by minimal state intrusion in the private sphere of consumption," (p. 65) and that the tobacco industry had a strong influence on these governments throughout the 1990s. 


\section{Box 6.1 The Dutch blockade of the EU tobacco advertising ban}

In 1990 Philip Morris intensified its lobbying efforts against the European advertising Directive (Dollisson, 1990) and very soon "the largest and best financed lobbying campaign ever mounted by tobacco and advertising companies" descended on the members of the European Parliament (Boessen, 2008, p. 77). Because the ban would be based on the EU's jurisdiction over the internal market (Article $95 \mathrm{EC}$ ), it was subject to qualified majority voting. For a minority to veto the ban, 26 or more votes were required. The minority at the time consisted of Denmark (3 votes), Germany (10), Greece (5), the Netherlands (5), and the United Kingdom (10). The Netherlands blocked the EU advertising ban for many years, for economic reasons and because it preferred self-regulation, but formally on the grounds that the EC had no legal competence in the field of public health (Boessen \& Maarse, 2008). According to a German civil servant, "most legal arguments, especially those regarding competence, were just smoke screens for countries who wanted to block the ban" (Boessen \& Maarse, 2008). Philip Morris tried to preserve Dutch opposition through "contacts with the trade ministry to keep the health minister from undermining the Dutch position" and planned to "continue lobbying all country EC ambassadors and health attachés" (Philip Morris, 1993a). In 1993 the Dutch government decided it would reconsider its blocking position only in the event that the Dutch vote became decisive.

A few months after the inauguration of the new Purple cabinet in August 1994, a resolution of the Ninth World Conference on Tobacco or Health in Paris condemned the Netherlands and two other countries for blocking EU advertising legislation (Slama, 1995). Blocking the implementation of the directive was "an international scandal and is detrimental to the health of all citizens of the European Union, and by example of the citizens in all developing regions of the world who look to the European Union for leadership in public health policy" (Tubiana, 1994).

In November 1995 the official position of the Dutch government was still that as long as an EU decision on advertising ban did not depend solely on the Dutch vote, the Dutch national policy was to 
continue to trust the industry that it could restrain its advertising and promotion efforts without needing direct governmental intrusion. $^{2}$ This changed in 1997 after Tony Blair's landslide election victory in the United Kingdom. The new UK Labour government decided to support the ban. Without the United Kingdom in the blocking group, the Dutch vote was no longer crucial. In November 1997 Health Minister Borst joined the United Kingdom in support of the EU proposal. The next month, at the EU Health Ministers' Council meeting, a majority of countries supported the advertising ban, paving the way for the EU to proceed. However, the industry managed to have the advertising Directive annulled by the European Court of Justice, after which a watered down version was adopted in 2003, resulting in Directive 98/43/EC. Denmark, the United Kingdom, France, and the Netherlands choose to use the original, more comprehensive, version of the advertising Directive as the basis for its national tobacco advertising and promotion ban (VWS, 2005).

\section{Impact of the EU on Tobacco Control}

The importance of the EU for tobacco control should not be undervalued. Very influential were the second Tobacco Advertising Directive (Directive 2003/33/EC or TAD-2), and the two Tobacco Product Directives (2001/37/EC (TPD-1) and 2014/40/EU (TPD-2)). Nowadays cross-border advertising and promotion of tobacco products is banned throughout the EU. TPD-2 mandated pictorial health warnings, which are now implemented throughout the EU. Other Directives harmonised tobacco taxes across the EU by setting minimum taxation levels, which led to higher prices in southern European countries and in those EU member states that joined in 2004 (ASPECT Consortium, 2004).

\section{Implementation of Divectives}

Transposition of EU tobacco regulation into national law is more or less a formality, since EU law supersedes national law. However, the tobacco industry may influence the interpretation of an EU law. Since both chambers of the parliament need to approve changes in existing national laws, this offers possibilities for lobbying. In the case of TPD-1, there were 
lengthy discussions in both houses of parliament about interpretations of the text, fuelled by claims from the industry that the Dutch interpretation was more far-reaching than strictly necessary. One issue was whether the black border around the new health warnings should be included or excluded from the warning space (Lie, Willemsen, De Vries, \& Fooks, 2016). Ultimately the Dutch government agreed to the industry's interpretation, against the advice of the EC. Other issues were the requirement for tobacco manufacturers to hand over lists of ingredients, and a ban on misleading wordings on cigarette packs such as "light" and "mild." There were long debates between both houses of parliament and the cabinet in 2002 , the result of intensive lobbying by the tobacco industry network through the Volkspartij voor Vrijheid en Democratie (People's Party for Freedom and Democracy) (VVD) and Christen-Democratisch Appèl (Christian Democratic Party) (CDA). Member of parliament Geert Wilders (then still with the VVD) questioned the government's interpretation that the ban on misleading descriptors such as "light" and "mild" implied that colouring associated with lightness and mildness must also be restricted, so that light shades would be prohibited. ${ }^{3} \mathrm{He}$ argued that this did not directly follow from the English text of the EU directive, although it might be derived from a strict choice of words in the Dutch translation. Health Minister Bomhoff agreed with Wilders that the Netherlands had no ambition to be a pioneer in Europe, since other countries did not seem to follow the more strict Dutch interpretation. The government asked the EC if they could "correct" the Dutch official translation, confirmed that the English text was leading and that differences in colours within the same brand were thus allowed.

\section{EU Recommendations}

EU's Recommendations are less committal than Directives, and are therefore perceived as less important by national policymakers. The EC has issued two Recommendations on tobacco control. The first, in 2003 (Recommendation 2003/54/EC), urged EU countries to develop comprehensive approaches to tobacco control, including measures to prevent tobacco sales to children, restricting access to vending machines, removing tobacco products from self-service displays, prohibiting alternative forms of tobacco promotion not covered by Directive 2003/33/EC, and implementing tax measures to discourage consumption. Since the Netherlands had just implemented its revised Tobacco Act, the EU 
Recommendation was hardly noted. The second Recommendation was about the protection of non-smokers and smoking cessation (in line with FCTC article 8), and dated from 2009 (2009/C296/02). It asked member states to optimise protection from exposure to tobacco smoke in workplaces, public places, and public transport. It also called on governments to provide smokers with adequate treatment for tobacco dependence, and to consider plain packaging of tobacco products. This latter idea was particularly threatening to the industry, which lobbied intensively to tone it down. Dutch civil servants were targeted as well (see Box 8.3 in Chap. 8 for a detailed account of how the industry tried to get plain packaging out of the Recommendation).

\section{The Principle of Subsidiarity}

In 1992 the EU introduced the criterion of subsidiarity, which means that the EU may only intervene by means of a Regulation or Directive if it can act more effectively than individual member states are able to. This principle made it harder to implement EU-wide tobacco control regulation and was explicitly used in industry argumentation. According to Philip Morris, "in order to delay EU action we shall dialogue with supportive governments (the United Kingdom, Germany, Holland and Denmark) to encourage their opposition to EU legislation on the grounds of subsidiarity" (Philip Morris, 1993b). This strategy was indeed frequently applied in the Netherlands, where it resonated well with Christian Democratic principles. Already, in the beginning of the 1990s, the Dutch government had rejected the proposal for a tobacco advertising Directive on the grounds that this could better be resolved at a national level. ${ }^{4}$ Box 6.1 talked about the Dutch government's opposition to the EU advertising ban. An internal industry document emphasised that "the United Kingdom and the Netherlands are the two member states which are the most opposed to the proposal, on the grounds of subsidiarity and proportionality. They believe that the means are too strong to achieve the objectives, and that the member states should regulate the situation themselves" (BAT, 1996). The same reasoning was heard in 2007 when the government replied to consultation from the EC about the best policy to protect Europeans from tobacco smoke (the green paper Towards a Europe free from tobacco smoke: Policy options at EU level (European Commission, 2007)). The advice of the government was to leave it to member states to decide on smoking bans, a decision motivated by increased negative public opinion of the 
Brussels bureaucracy in the Netherlands (De Goeij, 2007). Since 2006 not only the government but also both chambers of parliament have tested new EU regulations by conducting a "subsidiarity check," in response to increased calls from society to reduce the power of Brussels.

\section{Coordination of Tobacco Control Policy Across the EU}

In 2001, across country coordination between national- and EU-level tobacco control was strengthened by the establishment of a regulatory committee for tobacco control, under Article 10 of Directive 2001/37/ EC. Once a year officials from the European national health ministries met in this committee, coordinated by the EC's Health Directorate. They discussed the progress of implementation of EU regulations in the various countries and were informed by the EC of the next steps towards EU tobacco control. The Netherlands was a steadfast participant at these meetings, which were also attended by the Rijksinstituut voor Volksgezondheid en Milieu (National Institute for Public Health and the Environment) (RIVM) and sometimes by the Nederlandse Voedsel en Waren Autoriteit (Netherlands Food and Consumer Product Safety Authority) (NVWA) (European Commission, 2017b). In 2014 the committee was replaced by an "expert group"; it has basically the same civil servants, but meets about four times per year (European Commission, 2017a). There are subgroups on issues such as tobacco ingredients and electronic cigarettes. This is an important network for civil servants who work on tobacco control, because this is where they exchange experiences and can support each other over practical and legal problems related to the implementation of EU tobacco control regulations. It is also a platform where country representatives discuss measures that member states may take that go beyond minimum EU requirements, such as tobacco product display bans, higher age limits for sales, and plain packaging. According to a Dutch participant in these meetings, "international cooperation increases our knowledge and offers new insights to reduce tobacco use further" (Mackay, 2017). Tobacco control has also been an important topic during most of the meetings of the European health ministers, who convene about twice a year in Brussels. The influence of the European Health Council thus goes beyond the adoption of new regulations or recommendations: the ministers exchange ideas and may learn from colleagues how to advance tobacco control at the national level (ASPECT Consortium, 2004 , p. 115). 


\section{The World Health Organization}

WHO is a specialised agency of the United Nations concerned with international public health. It is the main driving force for global tobacco control (Mamudu, Cairney, \& Studlar, 2015). National tobacco control initiatives are increasingly developed in response to WHO recommendations and, after the FCTC treaty was adopted in 2015, following FCTC requirements. The FCTC treaty was the end station of a long process by experts and WHO officials working towards a global tobacco control treaty (Mamudu, Gonzalez, \& Glantz, 2011). According to WHO, the main pillars of a comprehensive tobacco control approach include measures that reduce the supply of tobacco (bans on tobacco advertising and promotion, and the use of taxation to increase tobacco prices), the demand for tobacco (mass media awareness campaigns and providing effective smoking cessation support to quitters), and the protection of non-smokers through smoking bans. These elements were already well known in the Netherlands in the 1980s (Baan, 1986) and are reminiscent of the recommendations from the earlier Health Council's report (Beernink \& Plokker, 1975). In this respect, the FCTC treaty did not offer novel ideas about how to tackle smoking for Dutch tobacco control advocates and Dutch government officials.

In 1994, the World Health Assembly adopted the "International Strategy for Tobacco Control" resolution, which finally, after a long process of negotiation between individual states, led to the FCTC. The treaty came into force in 2005, after the required 40 countries had ratified it. Since then the number of ratifying countries has risen to 180 , covering $89 \%$ of the world's population (Framework Convention Alliance, 2017). WHO initiated a process of negotiation between participating countries through a series of Conferences of the Parties (COPs) in which guidelines were developed with details on how FCTC articles should be interpreted and implemented.

The Netherlands was among the countries in the EU (others were supposedly Germany, the Czech Republic, Austria, and Slovakia) that were reluctant to sign the FCTC treaty. ${ }^{5}$ Only because Dutch civil servants downplayed the consequences for the national tobacco policy, emphasising that WHO had no sanctioning power and that the treaty did not contain strict obligations for the state, and by treating it as a low-key topic, was it possible to get it through the Dutch bureaucracy. The government presented the treaty for tacit approval to both chambers of parliament in 
December 2004. ${ }^{6}$ It did not go completely unnoticed, for CDA, VVD, and LPF raised concerns about how the treaty would affect the national cigar manufacturing industry. ${ }^{7}$ Furthermore, the Dutch Antilles and Aruba did not want to be subject to the treaty, because they were afraid that it could not be implemented and enforced in their part of the kingdom. ${ }^{8}$ Nevertheless, on 27 January 2005 the Netherlands ratified FCTC and the treaty came into force one month later.

\section{Importance of WHO's FCTC Treaty for the Netherlands}

The FCTC did not play a significant role in the Netherlands in the first years after ratification, although there was a passing reference to it in the National Tobacco Control Plan 2006-2010 (STIVORO, 2005; VWS, 2006) and the Partnership Stop Smoking9 identified FCTC as setting "minimum norms for an effective policy to reduce the harm from tobacco" (Partnership Stop met Roken, 2004). It seldom surfaced during the regular talks between the Stichting Volksgezondheid en Roken (Dutch Smoking or Health Foundation) (STIVORO) and civil servants from the Ministry of Health, where mutual tobacco control campaigns and activities were discussed. Officials from the ministry were content that they had succeeded in having the Netherlands sign and ratify the FCTC, without opposition from parliament. They avoided discussions about whether the Netherlands was sufficiently compliant. Dutch officials, including the Council of State, had taken a close look at the text of the treaty and concluded that, strictly speaking, the Netherlands was already complying with the main FCTC requirements. They felt they could argue that the government was compliant, although they knew that there were many areas where the FCTC text went further than the Tobacco Act-certainly in its spirit. ${ }^{10}$ One ex-civil servant commented: "We felt that we had already accomplished a lot at the time: the smoke-free workplaces and advertising bans. We had the feeling that it [FCTC] was too late and superfluous."11 There also was an understanding among bureaucrats that FCTC was mostly relevant to third-world countries, who could use the treaty as leverage to improve tobacco policy, but that it was less relevant in the Dutch context.

Around 2010 the FCTC was finally given more consideration, after the first Rutte cabinet announced that finance for tobacco control would be cut and tobacco control measures were to be reversed. STIVORO responded by emphasising the government's neglect of its FCTC require- 
ments. STIVORO became a member of the international lobbying organisation Framework Convention Alliance (FCA), set up in 1999 by the United Kingdom's Action on Smoking and Health (ASH) with support from WHO as a central coordinating network of tobacco control advocates during FCTC negotiations and to push governments to implement the FCTC (Gneiting \& Schmitz, 2016; Mamudu \& Glantz, 2009).

\section{Implementation of the FCTC Treaty}

By signing and ratifying the FCTC, a country commits to implementing the policies that are part of the treaty. Many elements in the FCTC are mandatory and even legally binding under international law. Governments are required periodically to report to $\mathrm{WHO}$ about progress in implementing the FCTC. Every two years, governments meet at a Conference of the Parties $(\mathrm{COP})^{12}$ where details of guidelines for implementation and interpretation of the treaty are discussed and established. COPs are opportunities for extensive lobbying, both on the part of the tobacco control community (organised by the Framework Convention Alliance), and the tobacco industry lobby (Kalra, Bansal, Wilson, \& Lasseter, 2017). Before and during COP meetings, governments try to come to agreement over the final text of new guidelines, which often requires compromises. This creates difficult situations in cases where the subject matter of the guideline is also on a national policy agenda, and government representatives may abstain from voting, in order not to undermine the (oftentimes more important) negotiations at the national parliament.

\section{The Role of NGO's}

Although FCTC is legally binding upon governments, just like in other UN treaties there are no effective enforcement mechanisms. It is therefore left to civil society to make governments accountable, and even challenge them in court in the case of non-compliance. In some countries, tobacco control non-governmental organisations (NGOs) published "shadow reports" that told a more critical story than the periodic implementation progress reports that governments have to send to the WHO. Inspired by a shadow report from Canada (Global Tobacco Control Forum, 2010), STIVORO published an FCTC shadow report in March 2011 on behalf of the Cancer Society, the Heart Foundation, and the Lung Foundation (Rennen \& Willemsen, 2012). The report gave a detailed account of 
shortcomings regarding the Dutch government's FCTC obligations. Member of parliament Esmé Wiegman (Christian Union party) questioned the health minister on the issue and tabled a motion that the government should develop a comprehensive tobacco control policy in line with FCTC. ${ }^{13}$ The Alliantie Nederland Rookvrij (Dutch Alliance for a smoke-free society) (ANR) presented a second shadow report in January 2015 , which again pointed to the huge gap between current tobacco control policy in the Netherlands and full implementation of the FCTC treaty, although it acknowledged that the government was getting back on track (Heijndijk \& Willemsen, 2015).

The correct implementation of one of the FCTC Articles (8.2) was put to the test in a court case by Clean Air Netherlands (CAN) against the Dutch State. In October 2014 the Supreme Court ruled that the Dutch government's decision to exempt small cafes from the smoking ban ran contrary to FCTC Article 8.2, which states that countries shall adopt legislation in order to protect citizens from exposure to tobacco smoke in indoor workplaces and other public places, and should therefore be considered binding. The government responded by reinforcing the smoking ban in all cafes. This was the first time anywhere in the world that a national court decided that an FCTC requirement outranked a contradictory national law (Campaign for smoke-free kids, 2014).

\section{FCTC's Article 5.3: Excluding the Industry from Tobacco Control Policymaking}

A key element in the FCTC treaty is Article 5.3, which aims to exclude tobacco industry lobbyists from the policymaking process. WHO FCTC Article 5.3 states: "In setting and implementing their public health policies with respect to tobacco control, Parties shall act to protect these policies from commercial and other vested interests of the tobacco industry in accordance with national law"(WHO, 2003). In 2008 at the third Conference of the Parties in Durham, South Africa, further guidelines for the implementation of Article 5.3 were approved (WHO, 2008). A few weeks later in a personal meeting in December, Dutch Health Minister Klink talked with the Stichting Sigaretten Industrie (Dutch Cigarette Manufacturers Association) (SSI) and Vereniging Nederlandse Kerftabakindustrie (Dutch Fine Cut Tobacco Industry Association) (VNK) about the consequences of the outcomes of the COP. Klink confirmed that the Netherlands had expressed reservations about the imple- 
mentation of the guidelines, declaring that because the sale of tobacco is a legal economic activity, it must remain possible to have contacts with all stakeholders, including the tobacco industry. According to a summary of the meeting written by the industry, Klink referred to the principle of subsidiarity, a central element in CDA ideology and central in EU regulation: "The Netherlands (...) should not have to implement FCTC guidelines if it already has a good prevention policy in place" (SSI \& VNK, 2009). Klink affirmed that he was happy to continue talking with the industry and hearing their side of the argument regarding tobacco control policy proposals.

Following frequent media attention and parliamentary questions about contacts between the government and the tobacco industry at the end of 2011 and the beginning of 2012, the Stichting Rookpreventie Jengd (Youth Smoking Prevention Foundation) (SRJ) took the State to court for violating Article 5.3. Under the Dutch Freedom of Information Act, it had obtained hundreds of documents revealing contacts between Dutch government officials and the tobacco industry over the period 2009-2014. Although the case was lost in court, the government did set up rules to clarify Article 5.3 requirements (Youth Smoking Prevention Foundation, 2015). This was facilitated by a report commissioned by ANR, which outlined to the government how it should implement the article (Oude Gracht Groep, 2015), and technical instructions from WHO on implementation of Article 5.3 (WHO, 2012). In September 2015 State Secretary van Rijn sent a letter to both chambers of parliament outlining the government's policy regarding contacts with the tobacco industry, ${ }^{14}$ and in March 2016 a protocol was published and sent to all levels of government (ministries, provinces, municipalities) (VWS, 2016). Government officials were required to be restrained in their contacts with the tobacco industry "to prevent the industry from having influence on policy. That is why contacts (...) must be restricted to matters of technical execution." Regular meetings were no longer allowed, contacts had to be transparent, and notes of meetings were to be published on the internet, including letters and email contacts. ${ }^{15}$ Cooperation with the industry as part of corporate social responsibility activities was regarded as subject to Article $\mathbf{5 . 3}$ as well. Since then, it has become substantially more difficult for industry representatives and lobbyists to get an appointment with a government official (Scheltema Beduin \& Ter Weele, 2015, pp. 65-66; Van der Lugt, 2016). 


\section{CONCLUSION}

Tobacco policy is no longer the exclusive domain of the national government. Sovereignty is shared with supranational legislative bodies, especially the EU and WHO. The EU has a notoriously weak tobacco control regime, with restricted jurisdiction (only binding regulation if it contributes to free movement of goods and services across the EU), a slow policy formation process subject to intensive industry lobby, and a tendency to adopt policies after they have been implemented at the national level by most member states. The Dutch government is generally critical of EU interference with national tobacco control policy, and weighs EU proposals against subsidiarity criteria. However, once an EU directive is adopted by the European parliament, the government must transpose it into national law and implement it. In this way, EU regulation has become an important aspect of national tobacco control policy. Most important are EU requirements regarding tobacco packaging and the product itself (tobacco product Directives). In addition to such "hard law," the European tobacco control community has become important as an inspiration and example for national policy efforts, facilitated by coordination from Brussels-based tobacco control advocacy organisations such as the ENSP and the Smoke Free Partnership (SFP), and the fact that government officials (including ministers) frequently confer with colleagues from other EU countries.

It took some time before WHO's FCTC Treaty, which was ratified by the Dutch government in 2005, became influential in the Netherlands. In the first five years after ratification, the treaty had no impact whatever, mainly because it was not recognised by health organisations as a powerful advocacy tool. Since WHO has no mechanism to enforce through sanctions, the main value of the FCTC is that national advocacy organisations can use it to put moral or legal pressure on the government to do more. Only when the Dutch government reversed tobacco control in 2010, and it became clear that the government was on a path of weakening its FCTC commitments, did the FCTC become the benchmark for tobacco control advocacy groups in the Netherlands.

\section{Notes}

1. See Lelieveldt and Princen (2011) for an introduction.

2. Parliamentary Papers, 1995-1996, 24126, nr. 7, p. 2. 
3. Proceedings II, 26 September 2002, 6, 344.

4. Parliamentary Papers, 1991-1992, 22300 KVI, nr. 36, p. 9.

5. Interview, 6 October 2015.

6. Parliamentary papers II, 2004-2005, 29927, nr. 1.

7. Parliamentary papers II, 2004-2005, 29927, nr. 3.

8. Parliamentary papers II, 2004-2005, 29927, nr. 2.

9. See Chap. 9 for a description of the Partnership.

10. Interview, 6 November 2015.

11. Interview, 20 October 2015.

12. The COP is the governing body of the WHO's FCTC and is comprised of all parties to the Convention.

13. Proceedings II, 2011-2012, 32,793, nr. 43; Motion nr. 41 (32,793).

14. Parliamentary Papers II, 2015-2016, 32,011, nr. 47.

15. They can be found on: https://www.rijksoverheid.nl/onderwerpen/ roken/transparant-over-contact-tabaksindustrie

\section{ReFERENCES}

Asare, B., Cairney, P., \& Studlar, D. T. (2009). Federalism and multilevel governance in tobacco policy: The European Union, the United Kingdom, and devolved UK institutions. Journal of Public Policy, 29, 79. https://doi. org/10.1017/s0143814x09000993

ASPECT Consortium. (2004). Tobacco or health in the European Union: Past, present and future. Luxembourg: European Commission.

Baan, B. (1986). Strategieen ter bevordering van het niet-roken. Nederlands Tijdschrift voor Geneeskunde, 130, 1232-1139.

BAT. (1996). EU issues. British American Tobacco Records, Bates No. 322122073-322122107. Retrieved from https://www.industrydocumentslibrary.ucsf.edu/tobacco/docs/rkyb0207

Beernink, J. F., \& Plokker, J. H. (1975). Maatregelen tot beperking van het roken. Advies van de Gezondheidsraad. Verslagen, Adviezen, Rapporten (Vol. 23). Leidschendam: Ministerie van Volksgezondheid en Milieuhygiëne.

Bitton, A., Neuman, M. D., \& Glantz, S. A. (2002). Tobacco industry attempts to subvert European Union tobacco advertising legislation. San Francisco, CA: Center for Tobacco Control Research and Education University of California.

Boessen, S. (2008). The politics of European health policy-making: An actor-centred institutionalist analysis (Doctoral dissertation), Maastricht University, Maastricht.

Boessen, S., \& Maarse, H. (2008). The impact of the treaty basis on health policy legislation in the European Union: A case study on the tobacco advertising directive. [20]. BMC Health Services Research, 8, 77. https://doi. org/10.1186/1472-6963-8-77 
Campaign for smoke-free kids. (2014). Dutch Association of CAN v. Netherlands. Retrieved October 30, 2013, from http://www.tobaccocontrollaws.org/litigation/decisions/nl-20141010-dutch-association-of-can-v.-ne

Costa, H., Gilmore, A. B., Peeters, S., McKee, M., \& Stuckler, D. (2014). Quantifying the influence of the tobacco industry on EU governance: Automated content analysis of the EU Tobacco Products Directive. Tobacco Control, 23(6), 473-478. https://doi.org/10.1136/tobaccocontrol-2014051822

De Goeij, J. I. M. (2007). Kabinetsreactie Groenboek rookvrij Europa. Dutch Tobacco Industry Collection, Bates No. JB0441. Retrieved from https://www. industrydocumentslibrary.ucsf.edu/tobacco/docs/tthb0191

Dollisson, J. (1990). EEC advertising directive. Philip Morris Records, Bates No. 2024671385-2024671388. Retrieved from http://legacy.library.ucsf.edu/ tid/box36e00/pdf?search=\%222024671385\%201388\%22

Duina, F., \& Kurzer, P. (2004). Smoke in your eyes: The struggle over tobacco control in the European Union. Journal of European Public Policy, 1, 57-77. https://doi.org/10.1080/1350176042000164307

European Commission. (1984). Cooperation at community level on health related problems. Communication from the Commission to the Council. Brussels: European Commission.

European Commission. (2007). Green paper towards a Europe free from tobacco smoke: Policy options at EU level. Brussels: European Commission, Directorate C-Public Health and Risk Assessment.

European Commission. (2017a). Register of communication expert groups and other similar entities: Group of experts on tobacco policy (E03150). Retrieved April 14, 2017, from http://ec.europa.eu/transparency/regexpert/index. $\mathrm{cfm} ? \mathrm{do}=$ groupDetail.groupDetail\&groupID $=3150$

European Commission. (2017b). Tobacco: All events. Retrieved July 7, 2017, from http://ec.europa.eu/health/tobacco/events/index_en.htm\#anchor6

Framework Convention Alliance. (2017). Latest ratifications of the WHO FCTC. Retrieved July 7, 2017, from http://www.fctc.org/about-fca/tobaccocontrol-treaty/latest-ratifications

Gilmore, A., \& McKee, M. (2004). Tobacco-control policy in the European Union. In E. A. Feldman \& R. Bayer (Eds.), Unfiltered: Conflicts over tobacco policy and public health (pp. 219-245). London: Harvard University Press.

Global Tobacco Control Forum. (2010). Canada's implementation of the Framework Convention on Tobacco Control: A civil society 'shadow report'. Ottawa: Global Tobacco Control Forum (GTCF).

Gneiting, U., \& Schmitz, H. P. (2016). Comparing global alcohol and tobacco control efforts: Network formation and evolution in international health governance. Health Policy Plan, 31(Suppl 1), i98-i109. https://doi.org/10.1093/ heapol/czvl25 
Hastings, G., \& Angus, K. (2004). The influence of the tobacco industry on European tobacco-control policy. In The ASPECT Consortium (Ed.), Tobacco or health in the European Union: Past, present and future. Luxembourg: European Commission.

Heijndijk, S. M., \& Willemsen, M. C. (2015). Dutch tobacco control: Moving towards the right track? FCTC Shadow Report 2014. Den Haag: Alliantie Nederland Rookvrij.

Kagan, R. A., \& Nelson, W. P. (2001). The politics of tobacco regulation in the United States. In R. Rabin \& S. Sugarman (Eds.), Regulating tobacco (pp. 11-38). New York: Oxford University Press.

Kalra, A., Bansal, P., Wilson, D., \& Lasseter, T. (2017). Inside Philip Morris' campaign to subvert the global anti-smoking treaty. Retrieved July 15, 2017, from https://www.reuters.com/investigates/special-report/pmi-who-fctc/

Lelieveldt, H., \& Princen, S. (2011). The politics of the European Union. Cambridge: Cambridge University Press.

Lie, J., Willemsen, M. C., De Vries, N. K., \& Fooks, G. (2016). The devil is in the detail: Tobacco industry political influence in the Dutch implementation of the 2001 EU Tobacco Products Directive. Tobacco Control, 25, 545-550. https:// doi.org/10.1136/tobaccocontrol-2015-052302

Mackay, C. (2017). Internationale samenwerking tegen tabak. Columns NET. Retrieved April 14, 2017, from http://columns-net.trimbos.nl/column03-2017

Mamudu, H., \& Glantz, S. A. (2009). Civil society and the negotiation of the Framework Convention on Tobacco Control. Global Public Health, 4(2), 150-168. https://doi.org/10.1080/17441690802095355

Mamudu, H., Gonzalez, M., \& Glantz, S. (2011). The nature, scope, and development of the global tobacco control epistemic community. American Journal of Public Health, 101(11), 2044-2054. https://doi.org/10.2105/ AJPH.2011.300303

Mamudu, H. M., Cairney, P., \& Studlar, D. T. (2015). Global public policy: Does the new venue for transnational tobacco control challenge the old way of doing things? Public Administration, 93(4), 856-873. https://doi.org/10.1111/ padm. 12143

Mandal, S., Gilmore, A. B., Collin, J., Weishaar, H., Smith, K., \& McKee, M. (2009). Block, amend, delay: Tobacco industry efforts to influence the European Union's Tobacco Products Directive (2001/37/EC). Bath: University of Bath, School for Health.

Marks, G., \& Hooghe, L. (2003). Contrasting visions of multi-level governance. In I. Bache \& M. Flinders (Eds.), Multi-level governance (pp. 15-30). Oxford: Oxford University Press.

Oude Gracht Groep. (2015). Onderzoeks- en adviesrapportage m.b.t. de uitvoering van 'Artikel 5.3 van het WHO-Kaderverdrag inzake tabaksontmoediging (FCTC)' in Nederland. 
Partnership Stop met Roken. (2004). Beleidsaanbevelingen voor de behandeling van tabaksverslaving. Den Haag: Partnership Stop met Roken.

Peeters, S., Costa, H., Stuckler, D., McKee, M., \& Gilmore, A. B. (2016). The revision of the 2014 European tobacco products directive: An analysis of the tobacco industry's attempts to 'break the health silo'. Tobacco Control, 25(1), 108-117. https://doi.org/10.1136/tobaccocontrol-2014-051919

Philip Morris. (1993a). Marketing freedoms. Philip Morris Records, Bates No. 2501021740-2501021746. Retrieved from http://legacy.library.ucsf.edu/ tid/wet19e00

Philip Morris. (1993b). Smoking restrictions 3 year plan. Philip Morris Records, Bates No. 2025497291-2025497303. Retrieved from http://legacy.library. ucsf.edu/tid/vlz88e00

Rennen, E., \& Willemsen, M. C. (2012). Dutch tobacco control: Out of control? FCTC shadow report 2011. Amsterdam: KWF Kankerbestrijding.

Scheltema Beduin, A., \& Ter Weele, W. (2015). Lifting the lid on lobbying: Enhancing trust in public decisionmaking in the Netherlands. Amsterdam: Transparency International Nederland.

Slama, K. (1995). Resolutions of the Ninth World Conference on Tobacco and Health. In K. Slama (Ed.), Tobacco and Health (pp. 1017-1018). New York: Springer.

SSI \& VNK. (2009). [Letter to Klink concerning talks about WHO FCTC draft guidelines on December 11]. Dutch Tobacco Industry Collection, Bates No. JB0413. Retrieved from https://www.industrydocumentslibrary.ucsf.edu/ tobacco/docs/hshb019l

STIVORO. (2005). Nationaal Programma Tabaksontmoediging 2006-2010. Den Haag: STIVORO.

Studlar, D. T. (2006). Tobacco control policy instruments in a shrinking world: How much policy learning? International Journal of Public Administration, 29, 367-396. https://doi.org/10.1080/01900690500437006

Tubiana, M. (1994). [Letter from Tubiana to Borst-Eilers and Prime Minister Kok]. Dutch Tobacco Industry Collection, Bates No. JB2584. Retrieved from https://www.industrydocumentslibrary.ucsf.edu/tobacco/docs/hphp0219

Van der Lugt, P. (Producer). (2016, May 20). Nieuwe tabaksregels dwingen industrie tot bezinning. [Written article]. Retrieved from https://www.ftm. $\mathrm{nl} /$ artikelen/nieuwe-sigarettenpakjes-doen-harde-tabakslobby-veranderen

Verschuuren, M. (2011). International policy overview: Smoking. Bilthoven: RIVM.

VWS. (2005). Tobacco Act: Tobacco control in the Netherlands (International Publication Series Health, Welfare and Sport no. 22). The Hague.

VWS. (2006). Nationaal Programma Tabaksontmoediging. Den Haag: Ministerie van VWS.

VWS. (2016). Protocol over de wijze van omgang met de tabaksindustrie. Den Haag: Ministerie van VWS. 
WHO. (2003). WHO framework convention on tobacco control. Geneva: World Health Organization.

WHO. (2008). Elaboration of guidelines for implementation of Article 5.3 of the Convention Conference of the Parties to the WHO Framework Convention on Tobacco Control Third session Durban, South Africa, 17-22 November 2008. Geneva: World Health Organisation.

WHO. (2012). Technical Resource for Country Implementation of WHO FCTC Article 5.3. Geneva: World Health Organization.

World Bank. (1999). Curbing the epidemic: Governments and the economics of tobacco control. Washington: The World Bank.

Youth Smoking Prevention Foundation. (2015). Huge progress made thanks to court case against Dutch State Retrieved May 26, 2017, from http://www. stichtingrookpreventiejeugd.nl/over-rookpreventie-jeugd/english/ item/67-huge-progress-made-thanks-to-court-case-against-dutch-state

Open Access This chapter is licensed under the terms of the Creative Commons Attribution 4.0 International License (http://creativecommons.org/licenses/ by $/ 4.0 /$ ), which permits use, sharing, adaptation, distribution and reproduction in any medium or format, as long as you give appropriate credit to the original author(s) and the source, provide a link to the Creative Commons license and indicate if changes were made.

The images or other third party material in this chapter are included in the chapter's Creative Commons license, unless indicated otherwise in a credit line to the material. If material is not included in the chapter's Creative Commons license and your intended use is not permitted by statutory regulation or exceeds the permitted use, you will need to obtain permission directly from the copyright holder.

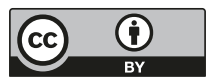

